\title{
Implementasi Pengembangan Keprofesian Berkelanjutan (PKB) Guru Madrasah dalam Meningkatkan Keprofesian
}

Ani Apiyani ${ }^{1}$, Yuli Supriani ${ }^{2}$, Sony Kuswandi ${ }^{3}$, Opan Arifudin ${ }^{4}$

1,2IAI Agus Salim Lampung, ${ }^{3}$ STIT Rakeyan Santang Karawang, ${ }^{4}$ Universitas Islam Nusantara Bandung E-mail:ani.apiani87@gmail.com,yulisupriani30@gmail.com,sony@rakeyansantang.ac.id,

opan.arifudin@yahoo.com

\section{Article Info \\ Article History \\ Keywords: \\ Development \\ Professional; \\ Continuous: \\ Teacher.}

Received: 2021-12-27

Revised: 2022-01-22

Published: 2022-02-03

\begin{abstract}
This study describes the study of the implementation of sustainable professional development (PKB) for madrasah tsanawiyah teachers in improving their professionalism. The method used in this study uses a library research method or approach, that library research can be interpreted as a series of activities related to the methods of collecting library data, reading and taking notes and processing research materials. The results of this study indicate that the program and implementation of teacher continuous professional development activities are carried out through teacher education and training which is reflected in learning, scientific publications with the preparation of teaching materials or modules, and the preparation of research in the field of education, as well as innovative work with the activities of making teaching aids and teaching aids. preparation of guidelines for exam and test questions in the form of a grid of exam questions or tests. Continuous professional development is expected to have an impact on increasing teacher competence which has an impact on the quality of students, both results and learning processes.
\end{abstract}

\begin{tabular}{l}
\hline Artikel Info \\
\hline Sejarah Artikel \\
Diterima: 2021-12-27 \\
Direvisi: 2022-01-22 \\
Dipublikasi: 2022-02-03
\end{tabular}

Kata kunci: Pengembangan; Keprofesian; Berkelanjutan; Guru.

\begin{abstract}
Abstrak
Penelitian ini menjelaskan tentang kajian terhadap implementasi pengembangan keprofesian berkelanjutan (PKB) guru madrasah tsanawiyah dalam meningkatkan keprofesian. Metode yang digunakan dalam kajian ini menggunakan metode atau pendekatan kepustakaan (library research), bahwa studi pustaka atau kepustakaan dapat diartikan sebagai serangkaian kegiatan yang berkenaan dengan metode pengumpulan data pustaka, membaca dan mencatat serta mengolah bahan penelitian. Hasil penelitian ini menunjukkan bahwa program dan implementasi kegiatan pengembangan keprofesian berkelanjutan guru dilaksanakan melalui pendidikan dan pelatihan guru yang direfleksikan dalam pembelajaran, publikasi ilmiah dengan kegiatan penyusunan bahan ajar atau modul, dan penyusunan penelitian dalam bidang pendidikan, serta karya inovatif dengan kegiatan pembuatan alat peraga serta penyusunan pedoman soal ujian dan ulangan berupa kisi-kisi soal ujian atau ulangan. Pengembangan keprofesian berkelanjutan diharapkan berdampak terhadap peningkatan kompetensi guru yang berdampak terhadap kualitas siswa baik hasil maupun proses pembelajaran.
\end{abstract}

\section{PENDAHULUAN}

Dalam rangka membangun sebuah bangsa yang maju dibutuhkan kualitas pendidikan sebagai sebuah upaya dalam menghasilkan sumber daya manusia yang berkualitas dalam mengisi seluruh sendi-sendi kehidupan berbangsa, pendidikan merupakan salah satu aspek kehidupan yang sangat penting, dalam konteks penyelenggaraannya bahwa komponen-komponen dalam pendidikan seperti pendidik, peserta didik, lembaga pendidikan dan kurikulum pendidikan sangat mempengaruhi keberhasilan suatu pendidikan. Menurut (Arifudin, 2021) mengemukakan bahwa peran guru sangat krusial dalam mempengaruhi belajar siswa, dari hal itu maka kualitas guru sangat mempengaruhi keberhasilan suatu pendidikan Guru atau tenaga pendidik merupakan salah satu faktor penentu tercapainya mutu pendidikan (Tanjung, 2021). Pendidik dan tenaga kependidikan merupakan salah satu dari Standar Nasional Pendidikan yang memerlukan perhatian khusus dari pemerintah dan masyarakat, pendidik dan tenaga kependidikan dalam proses pendidikan memegang peran strategis terutama membentuk watak bangsa melalui pengembangan kepribadian dan nilai-nilai yang diinginkan, beberapa fakta menunjukkan bahwa per-masalahan pendidikan yang dihadapi bangsa Indonesia adalah masih rendahnya mutu pendidikan pada setiap jenjang pendidikan, rendahnya mutu pendidikan dipengaruhi oleh beberapa faktor, salah satunya adalah proses pembelajaran 
yang belum mampu menciptakan proses pembelajaran yang berkualitas. Proses belajar mengajar yang diharapkan seorang guru adalah adanya perubahan pada aspek kognitif, afektif dan psikomotorik peserta didik, sehingga pekerjaan ini tidak dapat dilakukan selain seorang guru yang memenuhi standar professional. Hal tersebut bertujuan agar proses dan hasil belajar mengajar terlaksana secara optimal, manajemen peningkatan mutu sekolah dapat dilaksanakan dengan baik apabila didukung oleh keberadaan guru yang profesional dengan melakukan berbagai pengembangan sesuai dengan kebutuhan sekolahnya masing-masing. Sesuai tanggung jawabnya bahwa guru adalah tenaga pendidik tenaga profesional yang memiliki peran besar dalam upaya peningkatan mutu pendidikan dan tujuan pendidikan (Tanjung, 2020). Hal ini merujuk sebagaimana dijelaskan dalam undangundang nomor 14 tahun 2005 tentang guru dan dosen bahwa: "pendidik profesional dengan tugas utama mendidik, mengajar, membimbing, mengarahkan, melatih, menilai, dan mengevaluasi peserta didik pada pendidikan anak usia dini, jalur pendidikan formal, pendidikan dasar, dan pendidikan menengah". Setiap perubahan berbagai kebijakan dibidang pendidikan bertumpu pada sumber daya manusia yaitu pendidik atau guru karena peran guru sangat strategis dan merupakan faktor utama untuk menentukan mutu pendidikan karena guru berhadapan langsung dengan peserta didik atau siswa di kelas melalui proses pembelajaran (Kusnandar, 2007).

\section{METODE PENELITIAN}

Sesuai dengan karakteristik masalah yang diangkat dalam penelitan ini maka menggunakan Metode Riset kualitatif yaitu menekankan analisanya pada data deskriptif berupa kata-kata tertulis yang diamati, pendekatan kualitatif penulis gunakan untuk menganalisis kajian terhadap implementasi pengembangan ke-profesian berkelanjutan (PKB) guru madrasah tsanawiyah dalam meningkatkan keprofesian. Maka dengan sendirinya penganalisaan data ini lebih difokuskan pada Penelitian Kepustakaan (Library Research) yakni dengan membaca, menelaah dan mengkaji buku-buku dan sumber tulisan yang erat kaitannya dengan masalah yang dibahas (Ulfah, 2022). Metode yang digunakan dalam kajian ini menggunakan metode atau pendekatan kepustakaan (library research), menurut Zed dalam (Rahayu, 2020) bahwa studi pustaka atau kepustakaan dapat diartikan sebagai serangkaian kegiatan yang berkenaan dengan metode pengumpulan data pustaka, membaca dan mencatat serta mengolah bahan penelitian.

Jenis penelitian ini adalah penelitian kualitatif, menurut Ibnu dalam (Arifudin, 2018) penelitian kualitatif adalah suatu penelitian yang datanya dinyatakan dalam bentuk verbal dan dianalisis tanpa menggunakan teknik statistik. Berdasarkan beberapa definisi penelitian kualitatif di atas, dapat disimpulkan bahwa penelitian kualitatif adalah suatu penelitian yang datanya dinyatakan dalam bentuk verbal, tidak menggunakan angka dan analisisnya tanpa menggunakan teknik statistik.

1. Objek Penelitian

Dalam penelitian ini objek penelitian terdiri dari 2 (dua), yaitu objek formal dan objek material (Arifudin, 2019). Objek formal dalam penelitian ini berupa data yaitu data yang berhubungan dengan tinjauan kritis kajian terhadap implementasi pengembangan keprofesian berkelanjutan (PKB) guru madrasah tsanawiyah dalam meningkatkan keprofesian, sedangkan objek materialnya berupa sumber data, dalam hal ini adalah tinjauan kritis kajian terhadap implementasi pengembangan keprofesian berkelanjutan (PKB) guru madrasah tsanawiyah dalam meningkatkan keprofesian.

2. Waktu Penelitian

Penelitian ini dilaksanakan pada bulan November sampai dengan Desember tahun 2021.

3. Teknik Pengumpulan Data

Pengumpulan data yang dilakukan dengan menggunakan teknik dokumentasi yaitu mengadakan survey bahan kepustakaan untuk mengumpulkan bahan-bahan dan studi literatur yakni mempelajari bahan-bahan yang berkaitan dengan objek penelitian, teknik pengumpulan data menurut (Bahri, 2021) mengemukakan bahwa merupakan langkah yang paling strategis dalam penelitian karena tujuan utama dari penelitian adalah mendapatkan data. Terdapat beberapa cara atau teknik dalam mengumpulkan data, diantaranya adalah observasi dan dokumentasi, sumber data yang digunakan dalam penelitian ini mencakup data primer dan sekunder. Menurut (Hanafiah, 2021) bahwa data primer adalah data yang dikumpulkan langsung dari individu-individu yang diselidiki atau data tangan pertama. Sedangkan data sekunder adalah data yang ada dalam pustaka-pustaka, data primer dalam penelitian ini adalah buku- 
buku terkait tinjauan kritis kajian terhadap implementasi pengembangan keprofesian berkelanjutan (PKB) guru madrasah tsanawiyah dalam meningkatkan keprofesian, dan data sekunder didapatkan dari jurnal-jurnal baik nasional maupun internasional.

4. Alat Pengumpulan Data

Dalam penelitian ini penulis akan menggunakan metode dokumentasi sebagai alat untuk pengumpul data karena penelitian ini adalah penelitian kepustakaan, dengan kata lain, menurut (Juhji, 2020) bahwa teknik ini digunakan untuk menghimpun data-data dari sumber primer maupun sekunder.

5. Teknik Analisis Data

Analisis data tidak saja dilakukan setelah data terkumpul, tetapi sejak tahap pengumpulan data proses analisis telah dilakukan. Penulis menggunakan strategi analisis "kualitatif", strategi ini dimaksudkan bahwa analisis bertolak dari data-data dan bermuara pada kesimpulan-kesimpulan umum, berdasarkan pada strategi analisis data ini dalam rangka membentuk kesimpulan-kesimpulan umum analisis dapat dilakukan menggunakan kerangka pikir "induktif". Menurut (Sugiyono, 2015) bahwa metode pembahasan menggunakan metode deskriptif-analisis, yaitu menjelaskan serta mengkolaborasi ide-ide utama yang berkenaan dengan topik yang dibahas, kemudian menyajikannya secara kritis melalui sumber-sumber pustaka primer maupun skunder yang berkaitan dengan tema.

6. Prosedur Penelitian

Data pada penelitian ini dicatat, dipilih dan kemudian diklasifikasikan sesuai dengan kategori yang ada, pendekatan yang digunakan adalah pendekatan deskriptif analitis, menurut (Nasser, 2021) bahwa deskriptif analitis (descriptive of analyze research), yaitu pencarian berupa fakta, hasil dari ide pemikiran seseorang melalui cara mencari, menganalisis, membuat interpretasi serta melakukan generalisasi terhadap hasil penelitian yang dilakukan. Prosedur penelitian ini adalah untuk menghasilkan data deskriptif yang berupa data tertulis setelah melakukan analisis pemikiran (content analyze) dari suatu teks. Setelah penulis mengumpulkan bahan-bahan yang berhubungan dengan masalah yang akan dibahas dalam penelitian ini, kemudian penulis menganalisis dan menarasikan untuk diambil kesimpulan.

\section{HASIL DAN PEMBAHASAN}

Dalam pembahasan ini akan dibahas tentang Program PKB Bagi Guru-Guru Bersertifikasi Pendidik, dan Implementasi PKB Bagi Guru-Guru Bersertifikasi Pendidik.

1. Program PKB Bagi Guru-Guru Bersertifikasi Pendidik.

Program pengembangan keprofesian berkelanjutan (PKB) bagi guru adalah suatu proses kegiatan guru secara sistematis dengan memeriksa dan menilai atau refleksi guru setelah berlangsungnya kegiatan belajar mengajar untuk membenahi segala kekurangan yang berfungsi untuk meningkatkan keprofesionalannya (Kemendiknas, 2010). Program PKB berisi peningkatan kompetensi guru yaitu program penguasaan materi pembelajaran, struktur, konsep dan pola pikir keilmuan yang dapat mendukung mata pelajaran yang diampu melalui kegiatan pengembangan diri yang dilaksanakan secara mandiri atau diklat fungsional guru secara kolektif melalui kegiatan kelompok guru sejenis atau MGMP. Sedangkan program publikasi ilmiah dan karya inovatif merupakan kegiatan keprofesian berkelanjutan dari komponen mengembangkan keprofesian melalui tindakan reflektif (Permendiknas. nomor 16 Tahun 2007). Kebijakan dan Pengembangan Keprofesian Berkelanjutan untuk Guru, Kepala Madrasah dan Tenaga Kependidikan Madrasah, yakni:

a) Penguatan dan Perluasan akses untuk Kegiatan Kelompok Kerja Guru, Kepala Madrasah, dan Pengawas.

b) Program Penguatan dan Penyiapan Calon Kepala Madrasah dan Pengawas Madrasah.

c) Pengembangan Sumber Belajar dan Assessmen Kompetensi Guru (AKG) dalam Mendukung PKB Guru dan Tendik.

d) Penguatan Kapasitas Guru dan Tenaga Kependidikan Melalui Pelatihan.

Sasaran kelompok kerja pada Pengembangan Keprofesian Berkelanjutan (PKB) untuk Guru, Kepala Madrasah dan Tenaga Kependidikan Madrasah, yakni sebagai berikut:

a) KKG MI: Program Literasi, Numerasi, dan Sains di tingkat kecamatan atau gabungan kecamatan.

b) MGMP MTs: Tingkat Kabupaten/Kota atau gabungan Kabupaten/Kota untuk mata pelajaran Matematika, Bahasa Indonesia, Bahasa Inggris, dan Ilmu Pengetahuan Alam. 
c) MGMP MA: Tingkat Kabupaten/Kota atau gabungan Kabupaten/Kota untuk mata pelajaran Bahasa Indonesia, Bahasa Inggris, MTK, Fisika, Kimia, Biologi, dan Ekonomi.

d) MGBK MA: Tingkat Kabupaten/Kota atau gabungan Kabupaten/Kota.

e) KKM: Tingkat Kabupaten/Kota atau gabungan Kabupaten/Kota.

f) POKJAWAS: Tingkat Kabupaten/Kota atau gabungan Kabupaten/Kota, dan tingkat Provinsi

2. Implementasi PKB Bagi Guru-Guru Bersertifikasi Pendidik.

Pengembangan keprofesian sangat berpengaruh dalam mutu pendidikan di sekolah, sesuai hasil penelitian terdahulu oleh (Bustami, 2009), Pengaruh Pengembangan Profesionalisme Guru terhadap mutu pendidikan di Kabupaten Aceh Timur, dengan demikian pengembangan keprofesian harus berkaitan dengan pembelajaran atau direfleksikan berbagai kompenen kegiatan yang berhubungan dengan peningkatan kinerja guru atau berdampak pada guru dan peserta didik, dalam penelitian ini dijelaskan pengembangan keprofesian berkelanjutan yang direfleksikan ke kegiatan pembelajaran dapat berdampak pada siswa atau peserta didik, yaitu:

a) Siswa dapat lebih memahami konsep materi yang sesuai standar kompetensi dan standar kompetensi dasar yang dikembangkan guru dalam perencanaan pembelajaran dan pengembangan silabus.

b) Siswa dapat belajar secara aktif, kreatif, inovatif, dan menyenangkan sesuai dengan konsep rancangan pembelajaran guru yang akan dilaksanakan di kelas.

c) Siswa dapat terarah dalam kegiatan pembelajaran karena guru melaksanakan kegiatn sesuai rancangan pembelajaran hasil refleksi pengembangan keprofesian berkelanjutan.

Pengembangan keprofesian keberlanjutan (PKB) merupakan kewajiban guru untuk meningkatkan kinerja dan kompetensinya yang dilaksanakan secara mandiri atau kegiatan kolektif guru dengan kegiatan, yaitu: Pengembangan diri, kegiatan publikasi ilmiah, dan karya inovatif (Permendiknas nomor 35 Tahun 2010). Peningkatan profesional guru harus dikembangkan untuk mengahadapi tantangan tugas yang berat dalam pem- belajarann peserta didik (Irwansyah, 2021). Pengembangan profesional tersebut dengan berbagai kegiatan pendidikan, pelatihan, penelitian tindakan kelas dan berbagai kegiatan atau tindakan yang mendukung kinerja guru (Suyanto, 2013). Kegiatan pengembangan diri yang dilaksanakan guru untuk meningkatkan kompetensi dan keprofesiannya melalui pendidikan dan pelatihan (diklat) dan kegiatan fungsional guru baik secara mandiri atau melalui kegiatan kolektif dalam kurun waktu 1 (satu) tahun. Kegiatan tersebut berupa kursus, pelatihan, penataran, maupun berbagai bentuk diklat yang lain. Kegiatan kolektif guru dapat dilakukan melalui musyawarah guru serumpun mata pelajaran di sekolah atau bekerja sama dengan sekolah lain (MGMP, KKG) macam kegiatan berupa lokakarya, seminar, koloqium, diskusi panel atau bentuk pertemu-an ilmiah lainnya.

Presentasi pada forum ilmiah dalam hal ini guru bertindak sebagai pemrasaran dan/atau nara sumber pada seminar, lokakarya, koloqium atau diskusi ilmiah, baik yang diselenggarakan pada tingkat sekolah, MGMP, kabupaten/kota, provinsi, nasional, maupun internasional. Publikasi ilmiah berupa hasil penelitian atau gagasan ilmu bidang pendidikan formal, publikasi ilmiah dapat berupa karya tulis hasil penelitian, makalah tinjauan ilmiah di bidang pendidikan formal dan pembelajaran, tulisan ilmiah populer dan artikel ilmiah dalam bidang pendidikan. Karya ilmiah ini telah diterbitkan dalam jurnal ilmiah tertentu atau minimal telah diterbitkan dan diseminarkan di sekolah masing-masing yang disahkan oleh kepala sekolah dan disimpan di perpustakaan sekolah. Publikasi buku teks pelajaran, buku pengayaan atau pedoman guru, baik sebagai buku utama maupun buku pelengkap, modul/diktat pembelajaran per semester, buku dalam bidang pendidikan, karya terjemahan, dan buku pedoman guru. Keaslian buku ditunjukkan dengan pernyataan keaslian dari kepala sekolah atau dinas pendidikan setempat bagi guru yang mendapatkan tugas tambahan sebagai kepala sekolah. Kelancaran atau keberhasilan awal implementasi kegiatan pengembangan keprofesian berkelanjutan guru-guru dapat dilihat hasil refleksi kegiatan pengembangan keprofesian yang sedang dilaksanakan dari awal tahun pelajaran sampai akhir tahun pelajaran, yaitu: Kesesuaian kegiatan peningkatan kompetensi 
sesauai pengembangan keprofesian berkelanjutan berdasarkan portofolio atau dokumen hasil refleksi yang dimiliki guru-guru, usahausaha guru yang telah dilaksanakan dalam pengembangarn diri yang dilakukan selama 1 (satu) tahun, dampak kegiatan pengembangan keprofesian berkelanjutan terhadap kompetensi guru, sekolah dan siswa.

Kepala sekolah sebagai manajer di sekolah yaitu berperan sebagi motivator, supervisor, dan evaluator kegiatan menyusun program dan melaksanakan PKB guru-guru, kepala sekolah sebagai motivator yaitu berperan mendorong guru-guru melaksanakan kegiatan PKB untuk mencapai kompetensi paedagogik, sosial, kepribadaian dan keprofesian (Kemendiknas, 2010: 40). Kepala sekolah sebagai supervisor di sekolah berperan membantu dan membina guru untuk lebih profesional dalam berbagai kegiatan sehingga kualitas pembelajaran lebih baik (Doni, 2014). Berdasarkan pada pendapat tersebut bahwa kepala sekolah sebagai supervisor, motivator dan evaluator dalam kegiatan pengembangan keprofesian berkelanjutan (PKB) berperan untuk mengawasi kegiatan pengembangan keprofesian berkelanjutan yang dilaksanakan guru-guru (Na'im, 2021), Kepala sekolah berperan sebagai evaluator yaitu berperan menilai kinerja guru dan meneliti evaluasi diri guru sebagai dasar merekomendasi program dan pelaksanaan pengembangan keprofesian berkelanjutan guru sehingga dapat berjalan lancar sesuai dengan tujuan yang diharapkan yaitu meningkatkan profesional guru.

\section{SIMPULAN DAN SARAN}

\section{A. Simpulan}

Berdasarkan pemaparan pada penelitian implementasi pengembangan keprofesian berkelanjutan (PKB) guru madrasah tsanawiyah dalam meningkatkan keprofesian ini dapat disimpulkan bahwa program penge-mbangan keprofesian berkelanjutan yang dilaksanakan berdasar dokumen evaluasi diri guru dan penilaian kinerja guru pada kompo-nen kompetensi penguasaan materi, struktur, konsep dan pola pikir keilmuan yang mendukung mata pelajaran dan mengem-bangkan keprofesian melalui tindakan penge-mbangan diri untuk meningkatkan kompe-tensi yang berhubungan dengan tugas pokok guru, atau kegiatan publikasi ilmiah maupun karya inovatif dengan direfleksikan kedalam pembelajaran atau tindakan yang mendukung peningkatan kinerja sebagai guru yang profesional sehingga layak memiliki sebutan guru yang bermartabat di tengah-tengah masyarakat sebagai guru bersertifikasi. Pengembangan keprofesian berkelanjutan merupakan wahana pembinaan keprofesian bagi guruguru yang dapat meningkatkan harkat dan martabat di masyarakat sebagai guru yang profesional sehingga perlu adanya tindakan secara bertahap, berkesinambungan dan kepedulian pemangku kepentingan, PKB dapat memberikan dampak positif berbagai pihak guru, siswa dan sekolah dalam upaya mencapai tujuan pendidikan. Kepala sekolah memiliki peran untuk menumbuhkan atau motivasi profesional guru melalui supervisi, monitoring dan evaluasi maupun pembinaan dalam kegiatan pengembangan keprofesian berkelanjutan, dengan demikian perlu meningkatkan perannya agar kegiatan PKB yang dilaksanakan guru dapat berhasil dengan baik dan lancar.

\section{B. Saran}

Pembahasan terkait penelitian kajian terhadap implementasi pengembangan keprofesian berkelanjutan (PKB) guru madrasah tsanawiyah dalam meningkatkan keprofesian dalam penelitian ini masih sangat terbatas dan membutuhkan banyak masukan, saran untuk penulis selanjutnya adalah mengkaji lebih dalam dan secara komprehensif terkait kajian terhadap implementasi pengembangan keprofesian berkelanjutan (PKB) guru madrasah tsanawiyah dalam meningkatkan keprofesian.

\section{DAFTAR RUJUKAN}

Arifudin, 0. (2021). Konsep Dasar Pendidikan Anak Usia Dini. Bandung: Widina Bhakti Persada Bandung.

Arifudin, O. (2018). Pengaruh Pelatihan Dan Motivasi Terhadap Produktivitas Kerja Tenaga Kependidikan STIT Rakeyan Santang Karawang. MEA (Manajemen, Ekonomi, \& Akuntansi), 2(3), 209-218.

Arifudin, 0. (2019). Manajemen Sistem Penjaminan Mutu Internal (Spmi) Sebagai Upaya Meningkatkan Mutu Perguruan Tinggi. MEA (Manajemen, Ekonomi, \& Akuntansi), 3(1), 161-169. 
Bahri, A. S. (2021). Pengantar Penelitian Pendidikan (Sebuah Tinjauan Teori dan Praktis). Bandung: Widina Bhakti Persada.

Bustami. (2009). Pengaruh Pengembangan Profesionalisme Guru SMP Terhadap Peningkatan Mutu Pendidikan di Aceh Timur. Medan: Universitas Sumatera Utara.

Darmayani, S. (2021). Pembelajaran Digital. Bandung: Widina Bhakti Persada.

Doni. (2014). Manajemen Supervisi dan Kepemimpinan Kepala Sekolah. Bandung: Alfa Beta.

Farisi. (2012). Peran Kepala Sekolah dalam Peningkatan Motivasi Kerja Guru. Magelang.

Gill. (2012). Continuing Professional Development for English Language Teachers in the UK. British Council: English Agenda.

Hanafiah, H. (2021). Pelatihan Software Mendeley Dalam Peningkatan Kualitas Artikel Ilmiah Bagi Mahasiswa. Jurnal Karya Abdi Masyarakat, 5(2), 213-220.

Hasbi, I. (2021). Administrasi Pendidikan (Tinjauan Teori Dan Praktik). Bandung: Widina Bhakti Persada.

Indrawati. (2013). Peningkatan Profesionalisme Guru dan Upaya Pengembangannya Melalui $C P D / P K B$. Makalah dipresentasikan di hadapan Peserta FKI (Forum Kreativitas dan Karya Inovasi PTK IPA 2013, Bandung September 2013).

Irwansyah, R. (2021). Perkembangan Peserta Didik. Bandung : Widina Bhakti Persada.

Juhji. (2020). Manajemen Humas Sekolah. Bandung: Widina Bhakti Persada.

Kemenag. (2017). Hand out: Pedoman Progran Pengembangan Keprofesian Berkelanjutan (PPKB). Jakarta: Direktorat Jenderal Pendidikan Islam Kementerian Agama Republik Indonesia.

Kemendiknas. (2010). Pedoman Pengelolaan Pengembangan keprofesian berkelanjutan. Jakarta: Direktur Jendral PMPTK.
Koswara. (2008). Seluk Beluk Profesi Guru. Bandung: PT Pribumi Mekar.

Kusnandar. (2007). Guru Profesional Implementasi Kurikulum KTSP. Jakarta: Rajawali Pers.

Mulyasa. (2013). Uji Kompetensi dan Penilaian Kinerja Guru. Bandung: PT. Remaja Rosdakarya Offset.

Nasser, A. A. (2021). Sistem Penerimaan Siswa Baru Berbasis Web Dalam Meningkatkan Mutu Siswa Di Era Pandemi. Biormatika: Jurnal Ilmiah Fakultas Keguruan Dan Ilmu Pendidikan, 7(1), 100-109.

Rahayu, Y. N. (2020). Program Linier (Teori Dan Aplikasi). Bandung : Widina Bhakti Persada.

Sugiyono. (2015). Metode Penelitian Pendidikan (Pendekatan Kuantitatif,. Kualitatif dan $R \& D)$. Bandung : CV. Alfabeta.

Supriani, Y. (2022). Peran Manajemen Kepemimpinan dalam Pengelolaan Lembaga Pendidikan Islam. JIIP-Jurnal Ilmiah Ilmu Pendidikan, 5(1), 332-338.

Suyanto. (2013). Menjadi Guru Profesional. Jakarta : Erlangga.

Tanjung, R. (2020). Pengaruh Penilaian Diri Dan Efikasi Diri Terhadap Kepuasan Kerja Serta Implikasinya Terhadap Kinerja Guru. Jurnal Ilmiah MEA (Manajemen, Ekonomi, Dan Akuntansi), 4(1), 380-391.

Tanjung, R. (2021). Kompetensi Manajerial Kepala Sekolah Dalam Meningkatkan Kinerja Guru Sekolah Dasar. JIIP-Jurnal Ilmiah Ilmu Pendidikan, 4(4), 291-296. https://doi.org/10.54371/jiip.v4i4.272

Ulfah, U. (2022). Kepemimpinan Pendidikan di Era Disrupsi. JIIP-Jurnal Ilmiah Ilmu Pendidikan, 5(1), 153-161.

Widiani. (2015). Karya Inovatif Guru. Makalah disampaikan Pada workshop Pengembangan Diri, Publikasi Ilmiah, dan Karya Inovatif bagi Guru. Prosiding. Kabupaten Sleman, 2426 Februari 2015. 